\title{
Plant communities and landscapes of the Parque Nacional DE ZiNAVE, MoZAMBIQUE
}

Authors:

Marc Stalmans ${ }^{1}$

Mike Peel ${ }^{2}$

\section{Affiliations:}

${ }^{1}$ International

Conservation Services CC,

Nelspruit, South Africa

${ }^{2}$ Agricultural Research

Council, Nelspruit,

South Africa

Correspondence to:

Marc Stalmans

email:

stalmans@ics-consulting.

co.za

\section{Postal address:}

International Conservation

Services CC, PO Box

19139, Nelspruit 1200,

South Africa

\section{Keywords:}

Greater Limpopo

Transfrontier Park

(GLTP); Parque Nacional

de Zinave (PNZ); Save

River; sandveld; mopane; miombo

\section{Dates:}

Received: 14 Apr. 2009

Accepted: 11 Oct. 2009

Published: 11 Mar. 2010

How to cite this article: Stalmans, M. \& Peel, M., 2010, 'Plant communities and landscapes of the Parque Nacional de

Zinave, Mozambique',

Koedoe 52(1), Art. \#703,

11 pages. DOI: $10.4102 /$

koedoe.v52i1.703

This article is available at:

http:/ / www.koedoe.co.za

(C) 2010. The Authors. Licensee: OpenJournals Publishing. This work is licensed under the Creative Commons Attribution License.

\section{ABSTRACT}

The Parque Nacional de Zinave covers 400000 ha in Mozambique to the south of the Save River. Until recently, this park had been characterised by neglect and illegal hunting that caused the demise of most of its large wildlife. A recent initiative has been launched that aims at rehabilitating the park within the scope of the Greater Limpopo Transfrontier Park (GLTP). A vegetation map was required as input to its management plan. The three primary objectives of the study were, firstly, to understand the environmental and biotic determinants of the vegetation, secondly, to identify and describe individual plant communities in terms of species composition and structure along the roads in the study area and, thirdly, to delineate landscapes in terms of their plant community make-up, environmental as well as biotic determinants and distribution. This is the third survey and description of the landscapes of the national parks located in the Mozambique part of the GLTP.

A combination of fieldwork and analysis of LANDSAT satellite imagery was used. A total of 75 sample plots were surveyed. A brief subjective visual assessment was undertaken for another 114 sample points. The accuracy of the landscape map was evaluated by means of 582 points assessed during an aerial game count.

The ordination results clearly indicate the overriding importance of moisture availability in determining vegetation composition. Ten distinct plant communities were recognised. Different combinations of these plant communities can be grouped in six major landscapes, namely the Save River channel and river banks, Save riverine forest, Acacia nigrescens woodland landscape, mopane landscape, miombo landscape and sandveld landscape. The landscapes with their individual plant communities represent habitats that are highly suitable for the reintroduction of many game species that were lost during the latter part of the last century.

Conservation implication: No formal description and mapping of the vegetation existed for Zinave. The landscape map is a vital input for the management plan. The reintroduction of wildlife species that were exterminated during the civil war requires a selection of suitable habitats for the placement of the 'sanctuary' that will be used to ensure the initial security of the introduced animals. The landscape map of Zinave fits into the broader mapping of the Great Limpopo Transfrontier Park and Conservation Area (GLTFCA) for conservation planning purposes.

\section{INTRODUCTION}

The Parque Nacional de Zinave (Zinave National Park; PNZ) has been said to comprise some of the best wildlife habitats in southern Africa (Duarte \& Oreste 1999; Storer \& Dalquest 1967) and used to harbour a wide diversity of wildlife (see Table 1). It was initially declared a hunting concession in 1962 and was run by Mozambique Safarilandia. It was upgraded to national park status in 1972 . It covers some 400,000 ha in Mozambique to the south of the Save River and forms one of the major components of the Greater Limpopo Transfrontier Park (GLTP) (see Figure 1). A vegetation map was required as one of the essential building blocks for the drafting of its management plan (DNAC 2002) and as a critical element for the planning of management actions.

Few botanical surveys were carried out in Mozambique between 1980 and 1994, during the long period of internal conflict that affected much of the country (MICOA 1997). The extent of the area, its relative inaccessibility due to poor road infrastructure and the limited time available precluded a traditional finescale vegetation description and map of the PNZ.

Vegetation is often used as a surrogate or building block for the definition of habitats (Timberlake, Nobanda \& Mapaure 1993). The use of broad habitat units defined by a combination of environmental factors and vegetation would probably represent the most useful input for the drafting of the management plan. This is because such units are used differently by different species of wildlife. The units also usually differ in their ecological capacity and water availability and thus might require different fire regimes. Moreover, the units tend to differ in their sensitivity to utilisation and development.

This is the third survey and description of the landscapes of the national parks located in the Mozambican part of the GLTP. This follows the description of the landscapes of the Limpopo National Park (LNP) (Stalmans, Gertenbach \& Carvalho-Serfontein 2004) and those of the Banhine National Park (BNP) (Stalmans \& Wishart 2005). Difficult access, limited resources and a lack of previously published information have severely limited the sampling intensity, the extent of the descriptions and the detail of the mapping. Detailed vegetation sampling was, therefore, restricted to the areas adjacent to roads. Nevertheless, it is hoped that the initial published accounts of the vegetation and landscapes of these parks will provide a basis on which further research projects can expand, much as the level of knowledge of the Kruger National Park (KNP) has been improved upon over the years. Similar landscape mapping exercises have been undertaken in the KNP (Gertenbach 1983) and in the protected areas to the west of the KNP (Peel, Kruger \& MacFadyen 2007). 


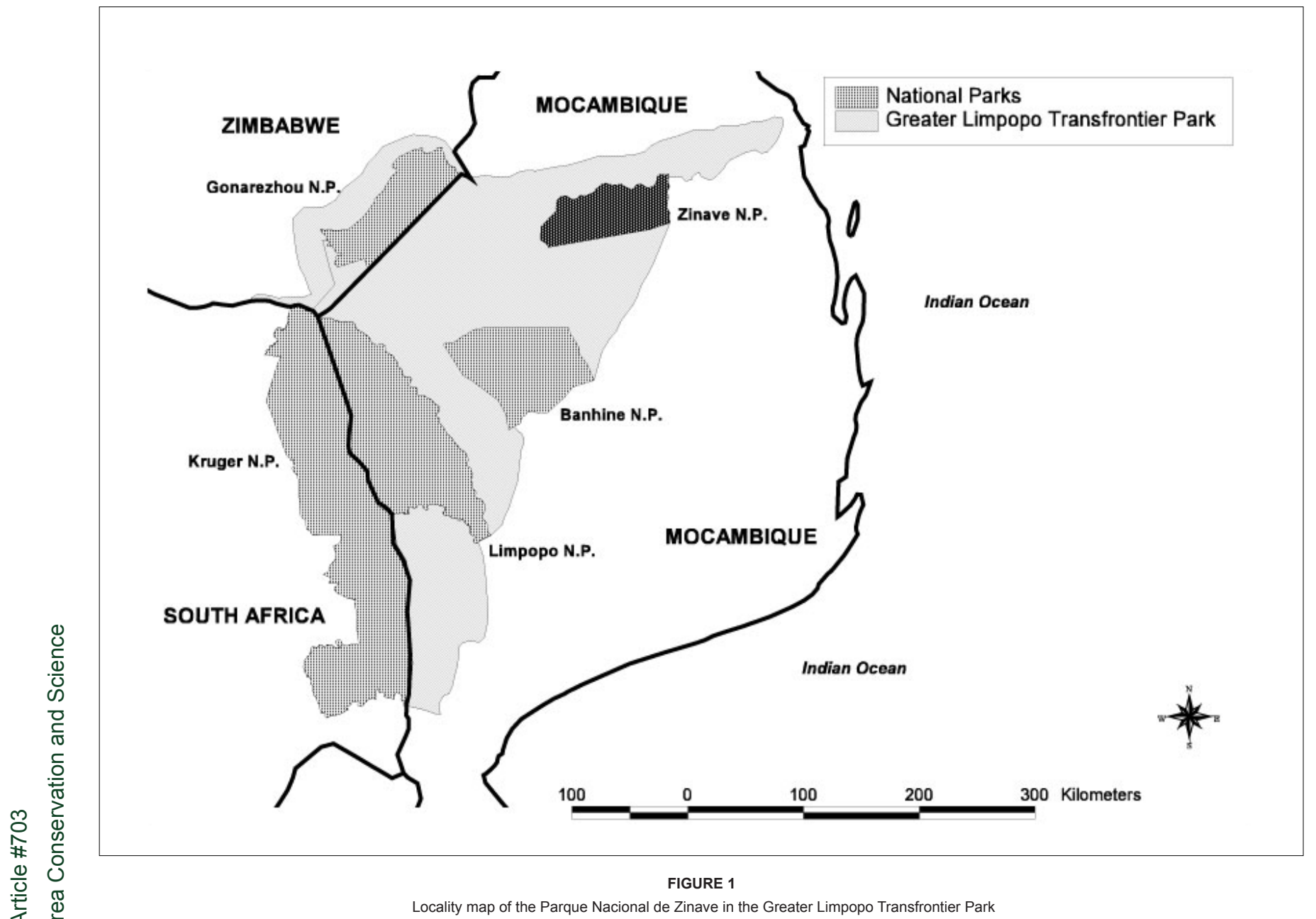

A similar conceptual approach to the LNP and BNP studies was followed, whereby landscapes were mapped explicitly, whereas the embedded plant communities are implied. A landscape is defined as 'an area with a specific geomorphology, climate, soil vegetation pattern and associated fauna' (Gertenbach 1983).

The objectives of this study were, firstly, to understand the environmental determinants of the vegetation, secondly, to identify and describe individual plant communities in terms of species composition and structure and, thirdly, to identify and delineate landscapes in terms of their plant community makeup, environmental determinants and occurrence.

\section{STUDY AREA}

The physical environment largely determines the vegetation composition and structure. The PNZ is situated between latitudes $21^{\circ} 21^{\prime} \mathrm{S}$ to $21^{\circ} 54^{\prime} \mathrm{S}$ and longitudes $33^{\circ} 2^{\prime} \mathrm{E}$ to $34^{\circ} 2^{\prime} \mathrm{E}$, in the Inhambane Province of Mozambique (see Figure 1), encompassing an area of approximately 400000 ha. The PNZ forms part of the GLTP with the LNP to the west and the BNP to the southwest. The highest elevation is on the southeastern boundary at $174 \mathrm{~m}$ above sea level. The area dips generally in a north-northeasterly direction with the lowest point at $110 \mathrm{~m}$ elevation on the northern boundary along the Save River. The area is underlain by arenaceous and argillaceous sediments with alluvium along the Save River (Departemento Terra e Agua 1995). The PNZ is mostly covered with sandy soils. Clayey soils derived from alluvial sediments occur along the Save River. These soils are susceptible to salination. The area is drained by numerous seasonal streams that run in an east-northeasterly direction towards the perennial Save River. A number of seasonal pans (some of which are quite large) are scattered across the park. A mean annual rainfall value of $690 \mathrm{~mm}$ applies to the northeastern sector of the ZNP, $613 \mathrm{~mm}$ in the southeast and $571 \mathrm{~mm}$ in the western sector, using the grid at 0.5 degree longitude/latitude resolution of the Leemans and Cramer (1991) database. Considerable variations can be expected within and between seasons (Kelly \& Walker 1976). The PNZ is located on the interface between the mopane and the miombo of the SudanoZambezian region, as described by Werger and Coetzee (1978) and Bandeira, Hatton, Munisse and Izidine (1994). The PNZ was established specifically for the conservation of important species such as giraffe (presently extinct) that historically only occurred in Mozambique south of the Save River (Smithers \& Lobão Tello 1976). Most of the original diverse and numerous large herbivores were largely decimated during the long civil war and its aftermath (see Table 1). The PNZ supports the subsistence of an estimated 4200 people in about 700 households located within the official park boundaries (DNAC 2002).

\section{Vegetation sampling}

\section{METHOD}

As access to the area can be very difficult due to flooding during summer, vegetation sampling was carried out at the end of the summer season and into the winter of June 2003. Although this is not ideal in terms of plant species identification, it was unavoidable.

A total of 75 plots of $40 \mathrm{~m} \times 40 \mathrm{~m}\left(160 \mathrm{~m}^{2}\right)$ were subjectively located in representative stands of vegetation to cover the altitudinal variation, soils and terrain position as determined from the topographical map and LANDSAT imagery. Sampling was limited to the areas adjacent to the road network during the ground survey (see Figure 2). 


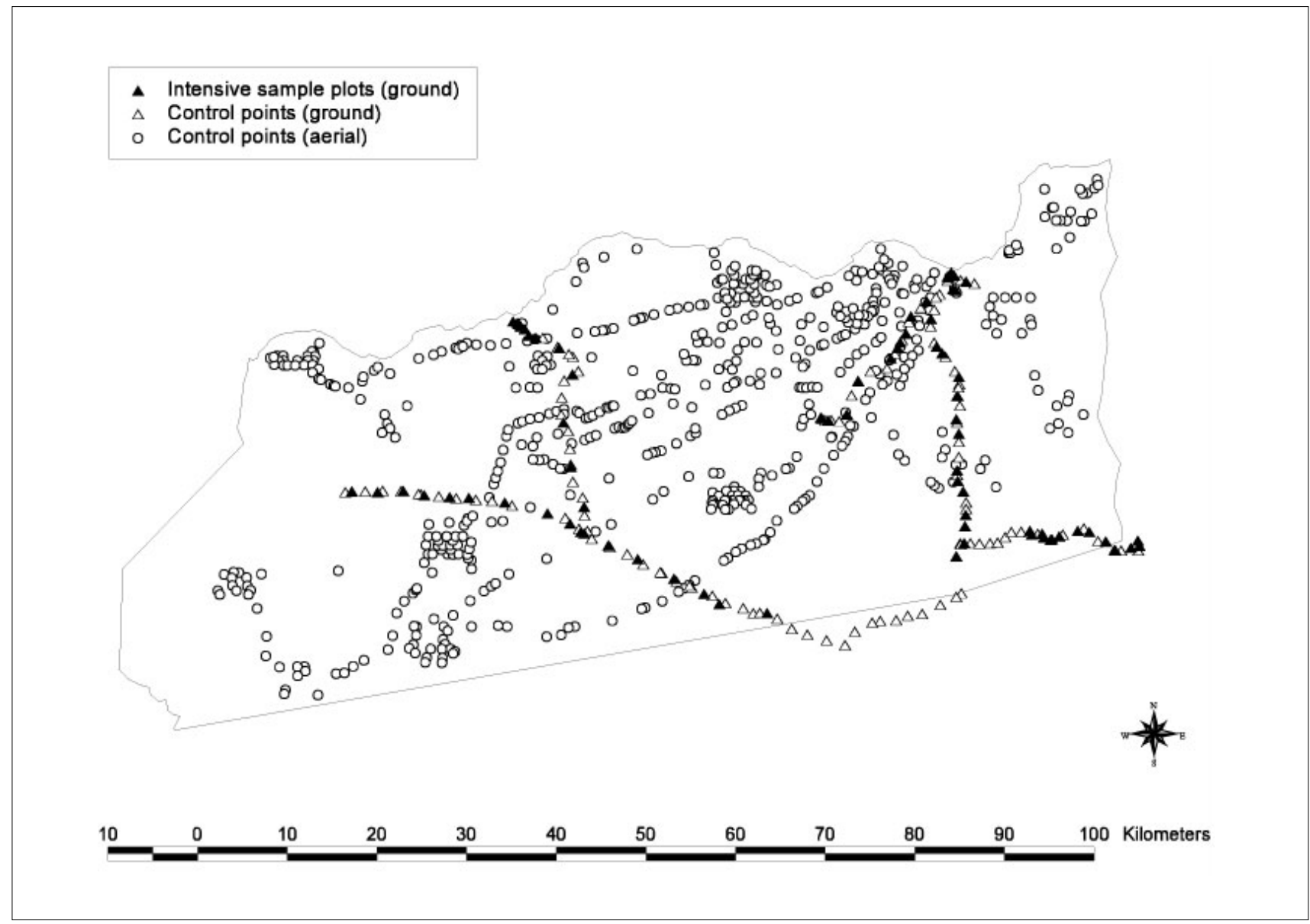

FIGURE 2

Position of vegetation sample plots as well as ground and aerial control points in the Parque Nacional de Zinave

Edwards (1983) structural classification was used to describe the overall structural properties of the sampled plots. Overall cover was estimated for the woody, grass, forb and geophyte component respectively using the semi-quantitative measures of the Braun-Blanquet approach (Mueller-Dombois \& Ellenberg 1974). Cover and height classes were recorded for individual woody and grass species. Records of environmental data included GPS position, geology, landscape position (Land Type Survey Staff 1989), slope, soil texture (using the sausage method; National Working Group for Vegetation Ecology 1986) and rockiness.

In order to further increase sampling intensity, 114 ground observation points were also used (see Figure 2). These consisted of a GPS point and subjective visual assessment relative to the formally surveyed sites. In 2007, during an aerial game count (Stalmans \& Peel 2007), a further 582 GPS points were assessed to improve the landscape map (see Figure 2).

\section{Analysis \\ Data were analysed through a combination of classification and ordination techniques. Classification was used to identify groups and to give structure to the raw data. Ordination of data was aimed at arranging species and samples in a low-dimensional space so that similar entities were close to one another and dissimilar entities far apart.}

Although more contemporary and sophisticated software packages are available for vegetation classification, the same techniques were used as those applied in the LNP (Stalmans et al. 2004) and BNP studies (Stalmans \& Wishart 2005) in order to maintain a uniform approach that is ultimately aimed at providing a single description of the entire GLTP.
A TWINSPAN (two-way indicator species analysis) classification (Hill 1979) was performed on the 75 sample plots. This is a polythetic divisive technique that is based on reciprocal averaging ordination (Gauch 1982). The simplicity and robustness of TWINSPAN as a hierarchical technique were appealing within the constraints of this particular study. It results in the definition of communities each characterised by its own distinctive species combination

The CANOCO package (Ter Braak 1992) was selected to analyse relationships between the data set of 75 plots and 168 species and the underlying environmental factors. CANOCO allows for canonical ordination, which is an intermediate technique that combines aspects of regular ordination with aspects of regression (Jongman, Ter Braak \& Van Tongeren 1987). The resulting ordination diagram expresses not only the pattern of variation in species composition but also the main features of species distributions along the gradient of environmental variables (Ter Braak 1986). Canonical coefficients, t-values of the regression coefficients and inter-set correlations of the environmental variables with axes are presented in the output of the canonical correspondence analysis (CCA). Canonical coefficients in a CCA are the equivalent of regression coefficients in indirect gradient analysis. They are coefficients of a weighted multiple regression of the sample scores on the standardised environmental variables. They have a larger variance than regression coefficients. When the $t$-value of a variable is less than 2.1, the variable does not contribute much to the fit of the species data in addition to the contributions of the other variables in the analysis. The inter-set correlations of environmental variables with axes are the correlation coefficients between the environmental variables and the species axes consisting of the sample scores. 


\section{Delineation of landscapes}

The relevant landscapes for the PNZ were identified using the knowledge gained through the ordination and classification of the PNZ field data. A combined approach was used to map these landscapes using the available soils map, the existing land cover map and the LANDSAT image. The land cover map (Carta de Uso e Cobertura da Terra) has been derived for Mozambique from LANDSAT satellite imagery at a scale of 1:250 000 (DINAGECA 1999). The PNZ comprises a total of 166 land cover polygons. A 'best fit' map of the landscapes was subjectively drawn by matching the individual land cover polygons to the field sampling data, the 114 ground observation points and the 582 aerial observations. Where required, polygon boundaries were manually edited following visual inspection of the satellite image and the recorded occurrence of the landscapes during the aerial survey. The coverage of the polygons by the available data set was assessed in order to derive a measure of certainty or uncertainty regarding the quality of the final landscape map.

\section{RESULTS AND DISCUSSION}

\section{Causal factors of vegetation pattern in the PNZ}

The first ordination run with the full set of 75 vegetation plots resulted in three distinct 'clouds' of sample plots in ordination space (see Figure 3). These 'clouds' represent respectively sample plots in riverine, floodplain or upland positions. The environmental variables 'drainage line' had a canonical coefficient of 0.97 on the second axis and 'floodplain' had a high canonical coefficient of 0.89 on the first axis. The different sample scores for these nominal environmental variables are represented within the ordination diagram by a single point, called the 'centroid'.

The 11 sample plots associated with the floodplain and drainage lines were removed from the data set and a new ordination was run. The resulting diagram identifies two outlying plots on the right of the diagram (see Figure 4). These two outliers represent two previously cultivated areas. These old lands are characterised by a combination of Melinis repens, Perotis patens and Tricholaena monachme in the grass layer. The parameter 'old land' has a canonical coefficient of 0.76 and t-value of 12.1 for the first axis. The parameter 'soil texture' has a canonical coefficient of 0.87 and $t$-value of 9.8 for the second axis. The sample plots are clearly spread in the diagram along the second axis with sandy substrates in the bottom-left corner (including miombo with Androstachys johnsonii) and more clayey soil (Acacia nigrescens woodlands) in the top-left corner of the diagram.

The successive ordination runs clearly indicate the overriding importance of moisture availability (in conjunction with soil texture) in determining vegetation composition in the PNZ. Firstly, the obvious differences in soil moisture availability by virtue of sample positions along drainage lines and in the floodplain came out of the first ordination. Thereafter, the gradient in soil clay content (as a result of underlying geological substrate and landscape position) and landscape position per se (in determining water flow) largely determine soil moisture and nutrient availability.

The interplay of soil moisture and soil nutrient availability conforms to the current understanding of the determinants of savanna systems. The four-determinant model gives moisture and nutrient availability equal status in establishing the range of possible forms that a savanna can assume (Scholes \& Walker 1993). Fire and herbivory then determine the actual form and function within that range. Similarly, Timberlake et al. (1993) consider soil moisture in this environment a major determinant in the distribution of vegetation types. Soil moisture availability results from the interaction between rainfall, topography, soil texture, soil depth, drainage and rooting habit of the plants. Siebert, Bredenkamp and Siebert (2003) identified a gradient of decreasing soil moisture availability along the first axis of ordination of more than 2000 sample plots in mopane veld straddling South Africa, Namibia and Botswana.

Within the GLTP, Stalmans (1994), Stalmans et al. (2004) and Stalmans and Wishart (2005) identified water availability

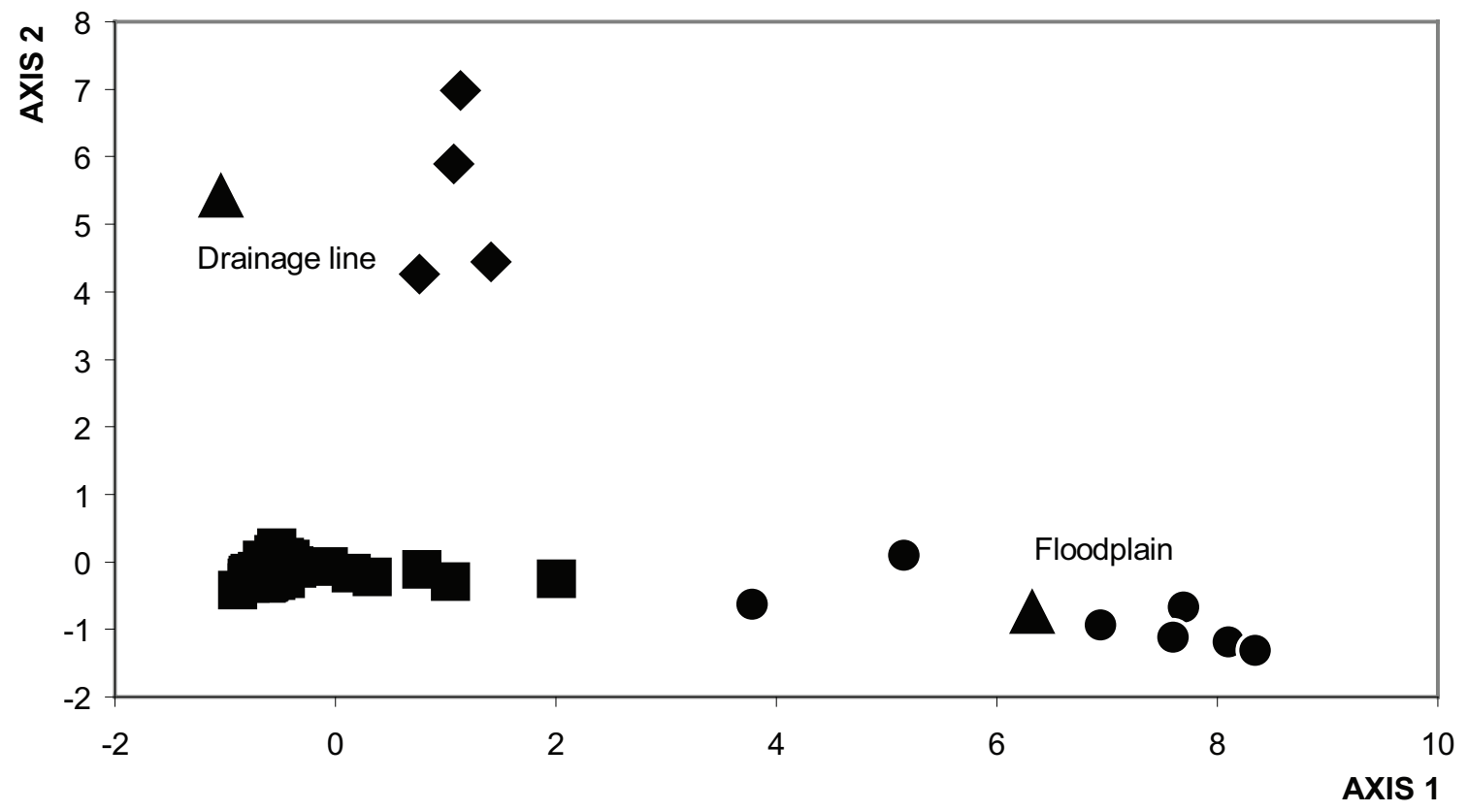

- Other plots 


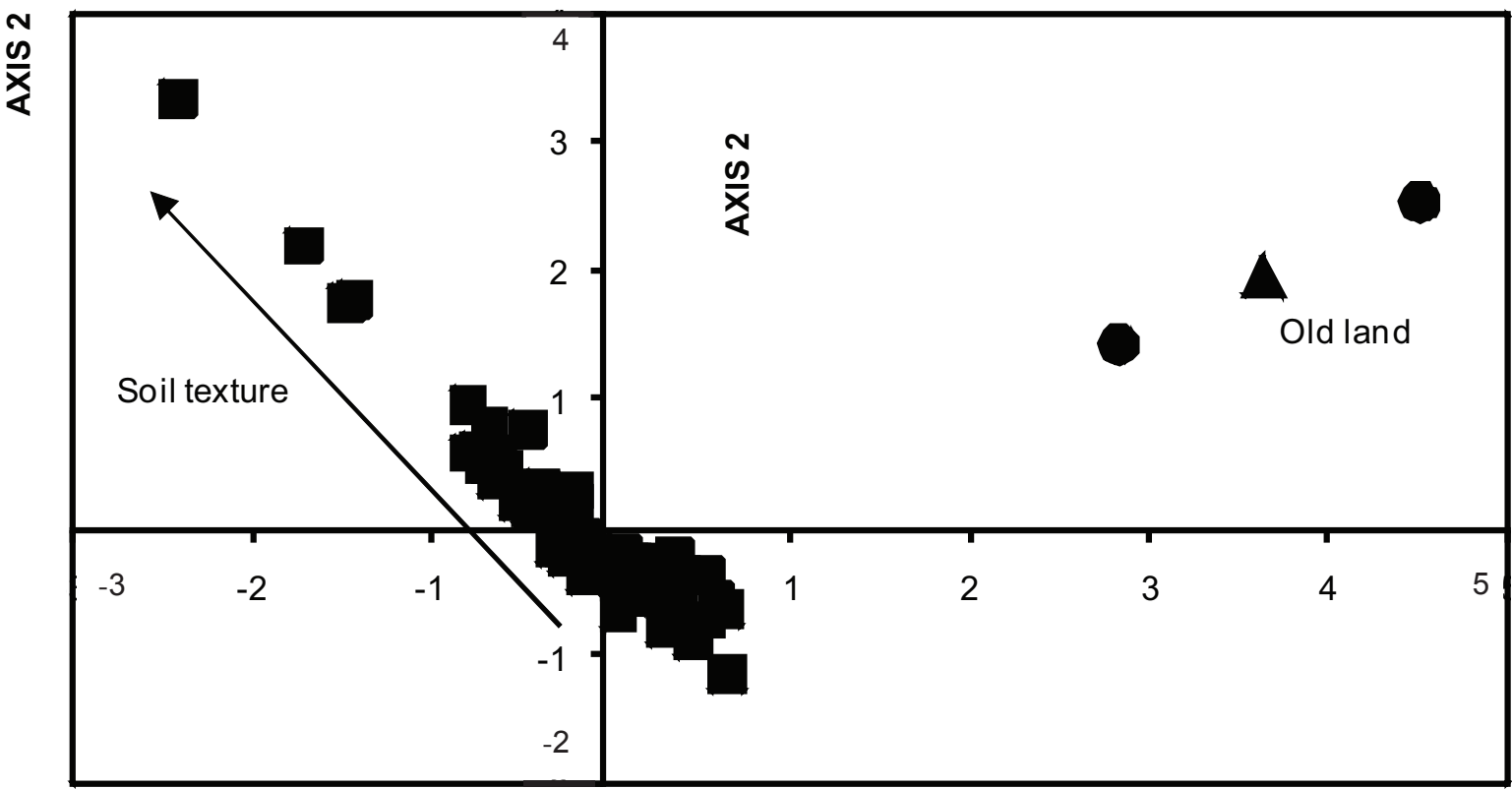

Otherplots lands

AXIS 1

FIGURE 4

CCA ordination biplot of 64 vegetation sample plots in the Parque Nacional Zinave, with the spread of samples aligned along a gradient of increasing clay content in the soil and where the CCA excluded sample plots along major drainage lines, on floodplains and on termite mounds, by using one quantitative (soil texture) and one nominal (land-use history) environmental variable

(as controlled by the position of the sample in the landscape and by its soil texture) as the major determinant of vegetation composition in an area adjacent to the Gonarezhou National Park in Zimbabwe, in the LNP and in the BNP respectively.

\section{TWINSPAN classification}

The results from the TWINSPAN classification are presented by means of a hierarchical diagram (see Figure 5). Starting from the top of the diagram, the set of 75 sample plots was divided into two groups. The left group represents the bulk of the sample plots $(n=73)$. The right group of two sample plots has as indicator the synthetic species 'No woody', meaning that the group is characterised by an absence of trees and shrubs. This is the vegetation of seasonally inundated pans and grasslands (Community 10) with as preferential species the grasses Eragrostis cf. heteromera and Paspalidium obtusifolium.

A group of four plots at Level 2 of the dendrogram represent Acacia xanthophloea woodland with tall grasses. Hyphaene petersiana and Sporobolus consimilis are the indicator species (Community 1 ). The remaining plots are split at Level 3 , in communities on fairly heavy soils (Communities 2 to 5 ) and those on sandy soils (Communities 6 to 9). The indicators for the left division (representing vegetation growing on clayey substrates) are Urochloa mosambicencis, Acacia nigrescens and Colophospermum mopane. The indicators for the right group (indicating a habitat with sandy substrates) are Hugonia orientalis and Monodora junodii.

The left group of Level 3 (clayey substrates) is split into a riverine component (Community 2) and a non-riverine assemblage at Level 4. The indicator species for the non-riverine vegetation are Urochloa mossabicensis, Colophospermum mopane and Digitaria eriantha. At Level 5, the remaining plots on clayey soils are split into true mopane woodlands (with Colophospermum mopane with a cover of $5 \%$ to $25 \%$ as indicator) (Communities 3 and 4 ) and Acacia nigrescens woodlands (Community 5) (with Acacia nigrescens and Sclerocarya birrea as indicator).
The right group of Level 3 (sandy substrates) divides at Level 4 into woodland and a near-forest (Community 9) component. The near-forest component has Acacia schweinfurtii as an indicator species and forest species such as Cordyla africana and Lecaniodiscus fraxinifolius as preferential species. The narrow fringe of vegetation found on the deep sands along the Save River splits off the remaining sandy plots at Level 5 (Community 8) with Ficus capreifolia being the indicator species. Finally, the remaining sandy vegetation is split at Level 6 into miombo (with Julbernardia globiflora, Heinsia crinita and Hymenocardia ulmoides as indicator species) (Community 6) and sandveld with Guibourtia conjugata woodlands (Community 7) (with Guibourtia and Alchornea laxiflora as indicator species).

\section{Definition of plant communities}

The community concept is applied in its broad sense and reflects a recurring assemblage of grass and woody species of characteristic composition and structure, growing in an area of essentially similar environmental conditions and land-use history (adapted from Gabriel \& Talbot 1984).

The classification outcome was evaluated subjectively against photographs of each sample plot. The main criterion applied was the need for each community to be identifiable in the field by an observer who is not necessarily a trained botanist. Community names were chosen subjectively so as to have practical value in the field through the use of two species that are visually and/or diagnostically important. The 10 communities that were identified broadly conform to the lower divisions of the dendrogram. They are therefore discussed from left to right following Figure 5.

\section{Plant communities}

1. Hyphaene petersiana - Acacia xanthophloea woodland: This community is situated to the south of the Save River in its floodplain, mostly on fairly heavy clays. A large proportion of this community is probably seasonally inundated. 


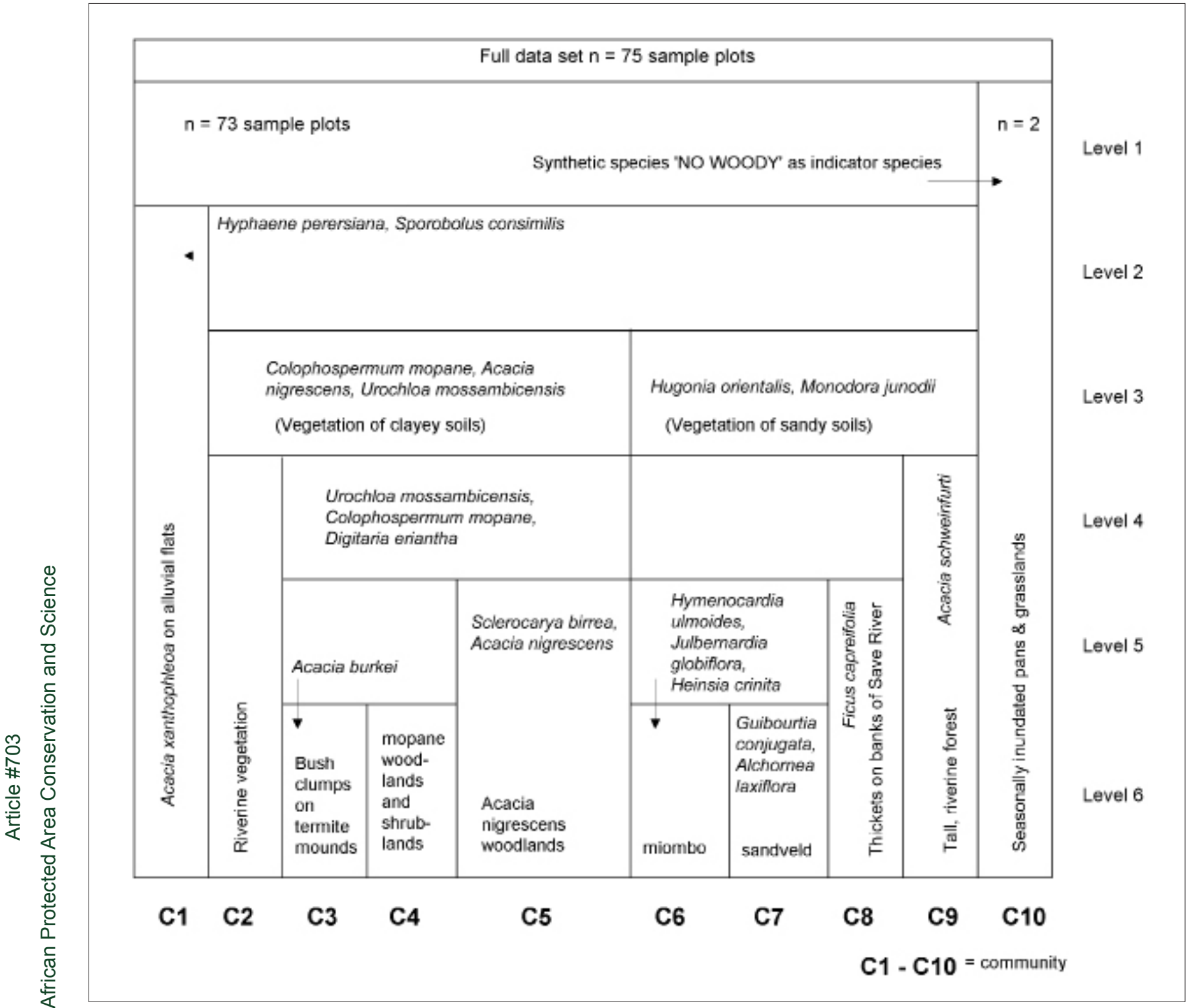

FIGURE 5

Hierarchical representation of the vegetation communities in the Parque Nacional de Zinave, where Levels 1 to 6 indicate increasing levels of homogeneity and specific composition and indicator species, as illustrated by the TWINSPAN classification, are underlined; communities that split off at an early level indicate a very distinctive and different assemblage from other communities

This woodland is characterised by Acacia xanthophloea, Salvadora persica and Hyphaene petersiana palms with a canopy height that is generally between $5 \mathrm{~m}$ and $10 \mathrm{~m}$. The grass layer is very dense and tall with a high frequency of Setaria incrassata and Panicum maximum. In drier areas on the edge of this community, the vegetation becomes shorter, with the grass layer less dense and more saline. This community corresponds to the Sporobolus consimilis - Setaria incrassata tall grassland found in the LNP (Stalmans et al. 2004). Van Rooyen, Theron and Grobbelaar (1981) similarly described Sporobolus consimilis grassland for the Limpopo floodplain in the KNP.

2. Acacia burkei - Andropogon gayanus woodland: This community is found along seasonal rivers, occupying a narrow strip between $10 \mathrm{~m}$ and $20 \mathrm{~m}$ wide, along these drainage lines. The vegetation has affinities with the surrounding vegetation away from the drainage line and is therefore not homogeneous across its distribution range. The species composition is thus variable, making a characterisation on a purely plant composition basis difficult. Acacia burkei and A. nigrescens are conspicuous as well as the grasses Andropogon gayanus and Eragrostis spp. It is the association of a wide range of species with the small drainage line conditions that sets this community apart.

3. Xanthocercis zambesiaca-Salvadora persica thickets: This community occurs as distinct bush clumps with a diameter of $20 \mathrm{~m}$ to $30 \mathrm{~m}$ on termitaria. These are embedded in the open Acacia nigrescens woodlands of Community 5 . Each clump is characterised by an emergent tree (often Xanthocercis zambesiaca - Nyala tree) that is surrounded by a variety of other species such as Grewia bicolor, Lecaniodiscus fraxinifolius, Salvadora persica and Maclura africana forming a 'skirt' around the core of the clump. This community is equivalent to the bush clumps found in the BNP that were assigned the same community name (Stalmans \& Wishart 2005). The grass layer is poorly developed and comprises mostly Panicum maximum.

4. Colophospermum mopane - Urochloa mosambicensis woodland: Mopane is the dominant species in tall, closed woodland, which becomes low closed shrubland where drainage is impeded. Other woody species have low cover values and include Combretum apiculatum, Dalbergia melanoxylon, Drypetes 
mossambicensis, Grewia bicolor and Flueggea virosa. The grass layer is dominated by palatable grasses such as Urochloa spp., Heteropogon contortus, Digitaria eriantha and Panicum maximum. This community has much affinity with the similarly named mopane woodlands found in the BNP (Stalmans \& Wishart 2005), the Colophospermum mopane - Panicum maximum woodland of the LNP (Stalmans et al. 2004) and the Digitaria milanjiana Colophospermum mopane vegetation type described by Siebert et al. (2003).

5. Acacia nigrescens - Urochloa mosambicensis woodland: This is generally open (but sometimes closed) tall woodland with Acacia nigrescens as an important and diagnostic species. Other important woody species are Sclerocarya birrea, Combretum imberbe, C. apiculatum, C. hereroense and Philenoptera violacea (previously Lonchocarpus capassa). The grass layer is dominated by palatable Urochloa spp., Heteropogon spp., Panicum maximum and Digitaria eriantha. This community, which is found mostly in the northeastern part of the PNZ, in a broad band between the Save River in the north and the mopane woodlands of Community 4 to the south, represents one of the most valuable grazing and browsing resources for wildlife in the park.

6. Julbernardia globiflora - Digitaria eriantha woodland: This is the typical 'miombo', consisting of a wide variation from Julbernardia-dominated short closed woodlands to majestic Brachystegia-dominated tall closed woodlands. Characteristic 'sandveld' specialists such as Hugonia orientalis, Pteleopsis myrtifolia, Cleistanthus schlechteri, Hymenocardia ulmoides and Xeroderris stuhlmannii are common. It includes patches of Androstachys johnsonii. These are, however, not classified by the TWINSPAN analysis as separate communities such as those found further west in BNP and the LNP. The Androstachys patches are generally more species rich than further west. This species may be close to the edge of its distribution range as a result of increasing rainfall. This community also encloses numerous large termite mounds ( $5 \mathrm{~m}-15 \mathrm{~m}$ diameter). These mounds are much more clayey than the surrounding sands on which the miombo is found. As a result species such as Boscia foetida, Manilkara mochisia and Thilachium africanum occur here. In comparison, miombo was not found in either the LNP or BNP.

7. Guibourtia conjugata - Digitaria eriantha woodland: This community generally consists of fairly open, but sometimes closed, woodland with a very characteristic appearance due to the abundance and striking form of Guibourtia conjugata and Milletia stuhlmannii. Other important woody species include Strychnos madagascariensis, Philenoptera bussei, Alchornea laxiflora, Brachystegia glaucescens and Lannea schweinfurtii. Panicum maximum is the most important grass after Digitaria eriantha. This community has many affinities to the Guibourtia conjugata - Eragrostis pallens woodlands described in the BNP (Stalmans \& Wishart 2005).

8. Pluchea dioscoridis - Digitaria eriantha thicket: This community occurs in a narrow strip on the banks of the Save River where it is subject to flooding disturbance. A heterogeneous mix of species occurs with the shrub Pluchea being the most frequent. Other species include Ficus capreifolia, Ziziphus rivularis, Grewia flavescens and G. sulcata. Occasionally, large Faidherbia albida form conspicuous copses on these banks. This community was relatively most affected by grazing and browsing by domestic goats. The regular deposition of fresh nutrients with the summer floods undoubtedly raises the quality of the grazing on these deep sands.

9. Cordyla africana - Philenoptera violacea forest: This closed community is found along the banks of the Save River on levees and other stable substrates. This is a mature community that takes many years to develop. It is not prone to flood disturbance to the same degree as Communities 1 and 8 . It is characterised by a tall canopy between $10 \mathrm{~m}$ and $20 \mathrm{~m}$ in height with large Cordyla africana, Philenoptera violacea, Sclerocarya birrea and Trichilia emetica. The large-leaved Grewia olukondae and the scrambling Acacia schweinfurtii are diagnostic species for this community.
Species in Zinave that are confined to this environment are Craibia zimmermannii, Cola natalensis, Tapura fisheri and Xylocarpus granatum. The grass layer consists mostly of Panicum maximum with some Setaria incrassata on the margins.

10. Paspalidium obtusifolium open grasslands: These open grasslands are found in pans that are distributed across the different landscapes of the ZNP. The blue water lily, Nymphaea nouchali, is often very conspicuous. The pans are often fringed by the tree Combretum imberbe. This community is equivalent to the similarly named community recorded in the BNP (Stalmans \& Wishart 2005). This represents the RAMSAR-defined wetland type Ts: 'seasonal/intermittent freshwater marshes/pools on inorganic soils; includes sloughs, potholes, seasonally flooded meadows, sedge marshes'.

\section{Definition of landscapes}

Not all of these 10 plant communities can be mapped individually, not even using the results of the satellite imagery analysis. They often occur in a fine-scaled mosaic that reflects small variations in topography and accompanying moisture regime. The current state of mapping of these environmental factors is not good enough to allow for the extrapolation and correlation of the vegetation into such fine-scaled mosaic. Broader units therefore had to be mapped. Landscapes have been defined that have bearing on management requirements and development potential as they represent a composite of topographical factors, underlying soil, hydrology and current vegetation pattern.

Different combinations of the plant communities can be grouped in six major landscapes (see Figure 6). Cultivated areas have been superimposed on the landscape map. Patches of seasonally inundated pans and grasslands occur in the miombo and mopane landscapes. Where they are sufficiently large, they have been individually mapped and are superimposed on the landscape map.

\section{Landscapes of the PNZ}

Save River channel and river banks: This landscape is very dynamic, encompassing $1.7 \%$ of the PNZ. When the river is in flood, most of this landscape would be under water. However, when the waters recede, large expanses of sand banks are exposed. These are clearly visible on the satellite image. The vegetated part of this landscape consists of Community 8 (Pluchea dioscorides - Digitaria eriantha thickets).

Save riverine forest: This landscape, which occupies $0.8 \%$ of the PNZ, occurs on the stable banks and levees south of the Save River that are not much influenced by flood dynamics. The landscape is primarily made up by Community 9 (Cordyla africana - Philenoptera violacea forest) and adjoining Community 1 (Hyphaene petersiana - Acacia xanthophloea woodland). This forest type consists of a very diverse assemblage of trees reaching heights of over $20 \mathrm{~m}$. This forest has been heavily impacted upon by shifting cultivation.

Acacia nigrescens woodland: This landscape, which covers $10.5 \%$ of the PNZ, mostly occurs on the brown soils derived from calcaric sedimentary rocks in an east-west band that lies south of the Save River. This landscape merges into the Save riverine forest to the north and into the mopane and miombo landscapes in the south. Large expanses of this landscape are found in the eastern half of the PNZ. Smaller patches were observed south of the Save River in the western part but could not be mapped. This landscape is principally made up by Community 5 Acacia nigrescens - Urochloa mosambicensis woodland, with bush clumps of Community 3 (Xanthocercis zambesiaca - Salvadora persica thickets) and Community 2 (Acacia burkei - Andropogon gayanus woodland) along the small seasonal rivers that drain this landscape towards the Save River. Large patches of mopane (Community 4) are also found. This landscape has strong affinities to the Sclerocarya birrea/Acacia nigrescens Landscape 17 described from the northern part of the KNP by Gertenbach (1983). 


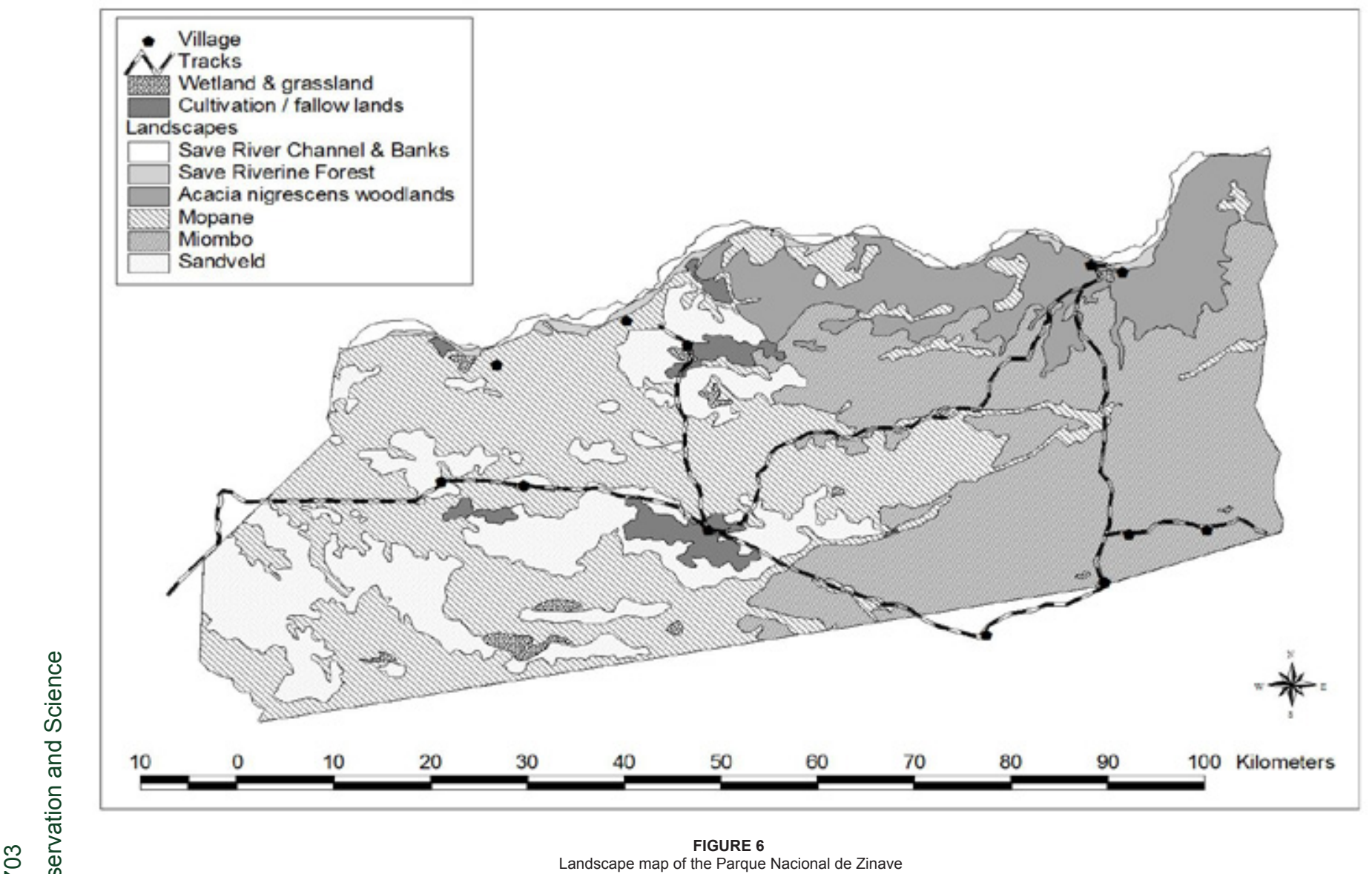

Mopane landscape: This landscape is found on heavier soils including the clayey colluvium derived from Mananga sediments and portions of the brown soils derived from calcaric sedimentary rocks. This is the most extensive landscape found in the PNZ; it covers $37.7 \%$ of the park. Its dominant feature is the mopanedominated closed woodlands of Community 4 (Colophospermum mopane - Urochloa mosambicensis woodlands) with Community 2 (Acacia burkei - Andropogon gayanus woodland) along the small seasonal rivers that drain this landscape towards the Save River. Seasonal pans with Community 10 (Paspalidium obtusifolium open grasslands) occur. Wetland type Ts (RAMSAR definition) is therefore represented here.

Sandveld landscape: This landscape was mostly encountered in the western sector of the park. It comprises mostly Community 7 Guibourtia conjugata - Digitaria eriantha open woodlands on deep reddish sandy soils that are characterised by relatively high $\mathrm{Ca}$ / $\mathrm{Mg}$ ratios and high $\mathrm{P}$ values. It adjoins both the miombo and mopane landscapes. The sandveld landscape is the dominant feature of the LNP and BNP; it covers respectively $41 \%$ and $46.7 \%$ of these parks (Stalmans et al. 2004; Stalmans \& Wishart 2005). However, it covers only $16.7 \%$ of the PNZ. Within the GLTP, the sandveld landscape appears to be gradually replaced in the east by the miombo landscape in response to a gradient of increasing rainfall towards the coast.

Miombolandscape: This landscape covers mostly the unspecified soils derived from sandy substrates and interior dunes as well as the unspecified soils derived from Mananga sediments. This is the second-most extensive landscape of the PNZ and covers $29.5 \%$ of the park. This landscape covers the higher lying part of the ZNP in the southeastern sector, representing the wetter part of the park. The miombo landscape extends in a northern and northwesterly direction where it becomes interwoven with the mopane and the sandveld landscape. The miombo landscape is primarily made up by Community 6 Julbernardia globiflora - Digitaria eriantha woodland. Seasonal pans comprising Community 10 (Paspalidium obtusifolium open grasslands) occur.
Wetland type Ts (RAMSAR definition) is therefore represented here. The size, density and regularity of tall termitaria are one of the prominent features of miombo landscapes (Desanker et al. 1997). The termitarium's soils have higher levels of total nitrogen, acid-extractable phosphorus and cations than surrounding soils due to both the concentration in and subsequent decomposition of organic matter within the mounds and the concentration of minerals through the evaporation of soil water in chimneys within the mound. These nutrient-rich patches within an otherwise nutrient-poor landscape invariably support distinctively different species and are often the focus of activity for birds and other animals that might otherwise not thrive so well in such a largely nutrient-poor environment.

\section{Accuracy of the landscape map}

The occurrence of sample plots and control points in the original land cover polygons of the Carta de Uso e Cobertura da Terra (DINAGECA 1999) provides a good idea of the level of certainty or uncertainty that can be associated with the landscape map (see Figure 7). The highest level of uncertainty is associated with the boundary areas. Although several land cover polygons were not sampled on the northern boundary, the well-known role of the riverine position in determining the vegetation make-up results in a much lower level of uncertainty than assumed from the map. Analysis of the satellite image strongly suggests that the poorly sampled areas in the east and west are covered by the miombo and mopane/sandveld landscapes respectively as mapped in Figure 6.

\section{Plant community diversity}

Time constraints and limited ground coverage did not allow for a detailed inventory of plant diversity. Therefore no inventory of forbs and geophytes was undertaken. The PNZ is very rich in tree species, with 208 woody species a recorded in the sample plots. Additionally, 41 species of grasses were noted. This species richness is evident if one considers that only 178 woody species 


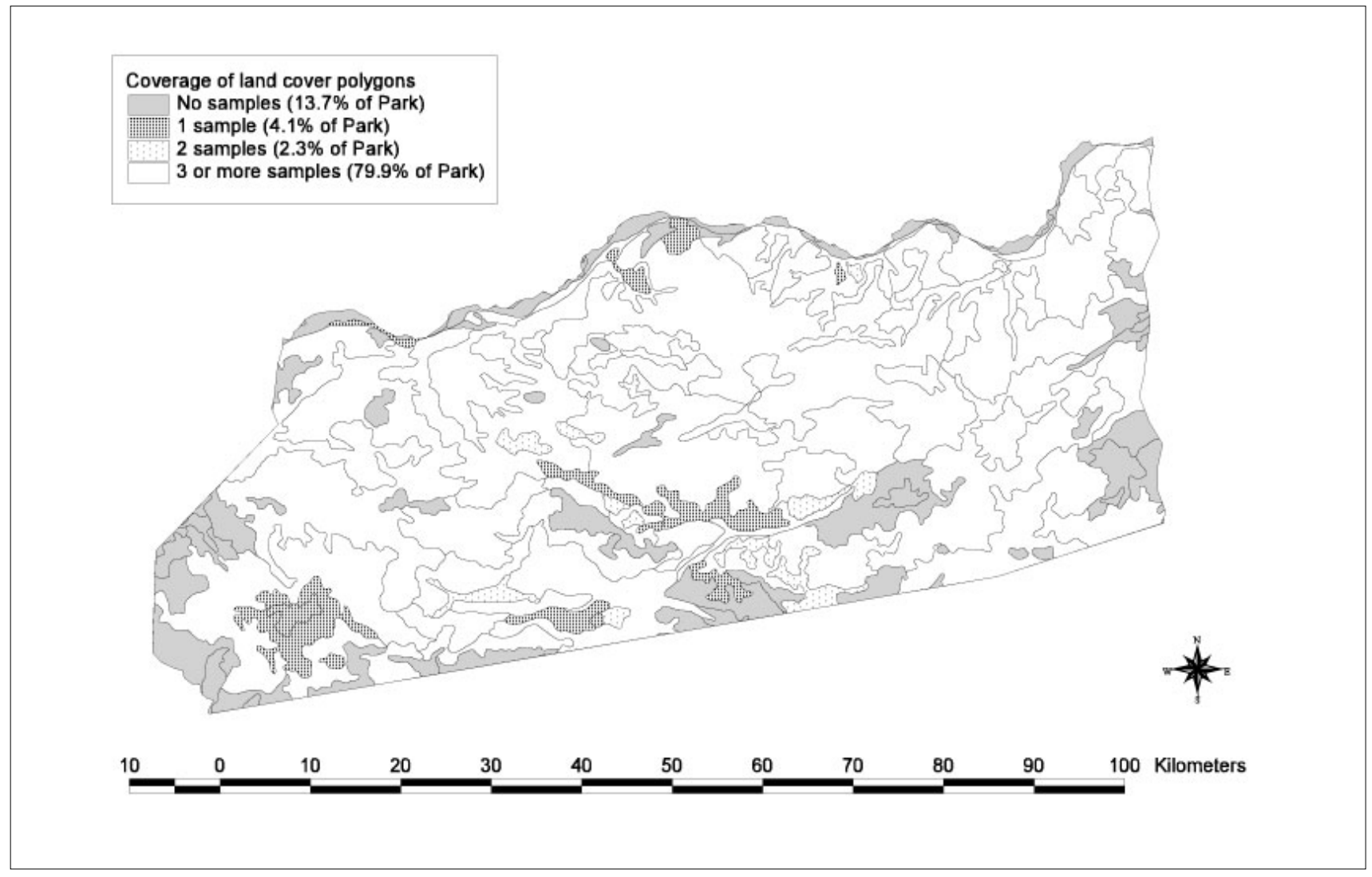

FIGURE 7

Sampling intensity across original land cover polygons in the Parque Nacional de Zinave; polygons with no or only one sample indicate greater uncertainty as to their correct landscape classifcation

were recorded in the much greater sample of 175 plots that were surveyed in the much larger LNP. It is of interest to note that a number of species were recorded during this survey that according to the generally used literature (Coates Palgrave et al. 2002) only occur much further north along the Zambezi and along the coast. These species include Xylocarpus granatum and Ficus bussei. This further strengthens the fact that very little is formally known about the vegetation of the PNZ highlighting the need for further studies.

\section{Land-use patterns and their influence on the vegetation of the PNZ}

A number of communities reside within the boundaries of the PNZ, living off subsistence farming and fishing. The subsistence farming is based on the Chitimene system of cultivation (shifting cultivation) whereby fields are cleared manually with farmers often cutting only the branches off trees and leaving the stems standing. The cut material is gathered and burnt in the central parts of the field. Crops are planted in the ash bed that provides nutrients. Androstachys patches are cleared preferentially in the miombo landscape. Julbernardia woodlands are also used for this subsistence farming. Farmers abandon the fields after 3-4 years of cultivation, allowing the miombo woodland to regenerate while new fields are cleared and planted. Cultivation of termitaria within the miombo was also observed whereby maize is planted in the fertile soil of the cleared/flattened termitarium. The edges of the pans are often also cultivated as the waters recede. The extent of the cultivated area is relatively limited and the impact is probably fairly small as the next flood cycle probably 'resets' the cultivated patch and surrounding areas to a comparable state. A significant impact was observed on the small extent of Save Riverine Forest landscape where clearing for cultivation is commonplace.

Although no formal assessment was made, much use is clearly made of trees for the building of dwellings and livestock pens and the carving of various items. The impact of these activities is selective. Whereas this use does not seem to impact significantly on the overall woody resource, no data are available on the impact on specific species.

Grass is cut and used for thatching. At least three species are cut and used for thatching (Heteropogon contortus, Eragrostis pallens and Aristida cf. adscensionis). Much use is made of medicinal plants and wild fruits (e.g. Strychnos spp.) but no data are available regarding the impact thereof on specific species.The largest selective impact through resource use is probably as a result of the harvesting of bark for the making of beehives. Long cylinders of bark are stripped from mostly Julbernardia globiflora, resulting in the death of the tree.

Due to the current low diversity and numbers of game, levels of herbivory (both grazing and browsing) are currently very low in the PNZ (see Table 1). Although both cattle and goats were observed grazing in the area, it appears that livestock numbers are also relatively low and with the exception of a single sample plot, only light grazing was observed.

The grass and tree layer is generally in an excellent condition, offering a suitable habitat for the herbivores that could be expected in this environment (both those occurring historically and those still present; see Table 1).

During this vegetation survey, Opuntia ficus-indica (prickly pear) was the worst invader species observed. It occurs in a few dense stands on the southeastern border in the Miombo landscape. Agave sisalana was also observed on the southeastern border as well as Ricinus communis on the banks of the Save River. It is supposed that because of the higher rainfall and extensive riverine fringe (that is affected by annual flood disturbance) the PNZ is relatively susceptible to alien plant invasion. 
TABLE 1

Historical and current occurrence of wildlife species in the Parque Nacional de Zinave

\begin{tabular}{|c|c|}
\hline Species that occurred in historic times & Current stuatus \\
\hline Black rhino (Diceros bicornis) & Locally extinct \\
\hline Buffalo (Syncerus caffer) & Probably $<10$ \\
\hline Bushbuck (Tragelaphus scriptus) & Viable population \\
\hline Bushpig (Potamochoerus porcus) & Viable population \\
\hline Cheetah (Acinonyx jubatus) & Unconfirmed reports - very low numbers \\
\hline Common reedbuck (Redunca arindinum) & Very few \\
\hline Eland (Taurotragus oryx) & Unconfirmed reports - very low numbers \\
\hline Elephant (Loxodonta africana) & Locally extinct \\
\hline Giraffe (Giraffa camelopardalis) & Locally extinct \\
\hline Grey duiker (Sylvicapra grimmia) & Viable population \\
\hline Hippo (Hippopotamus amphibius) & Viable population \\
\hline Impala (Aepyceros melampus) & Viable population \\
\hline Klipspringer (Oreotragus oreotragus) & Unknown \\
\hline Kudu (Tragelaphus strepciseros) & Viable population \\
\hline Leopard (Panthera pardus) & Some still present \\
\hline Lichtenstein hartebeest (Sigmoceros lichtensteinii) & Locally extinct \\
\hline Lion (Panthera leo) & Nomads pass through \\
\hline Nyala (Tragelaphus angasii) & Viable population \\
\hline Oribi (Ourebia ourebi) & Viable population \\
\hline Roan antelope (Hippotragus equinus) & Locally extinct \\
\hline Sable antelope (Hippotragus niger) & Locally extinct \\
\hline Sharpe's grysbok (Raphicerus sharpei) & Very low numbers \\
\hline Spotted hyena (Crocuta crocuta) & A very few still present \\
\hline Steenbok (Raphicerus campestris) & Viable population \\
\hline Suni (Neotragus moschatus) & Unknown \\
\hline Warthog (Phacochoerus aethiopicus) & Low, but viable population \\
\hline Waterbuck (Kobus ellipsiprymnus) & Very low numbers \\
\hline Wild dog (Lycaon pictus) & Unknown \\
\hline Wildebeest (Connochaetes taurinus) & Locally extinct \\
\hline Zebra (Equus burchelli) & Locally extinct \\
\hline
\end{tabular}

\section{ACKNOWLEDGEMENTS}

The vegetation research was undertaken during 2003, as part of the planning work by Development Alternatives Inc. and funded by USAID, in support to the Direcção Nacional de Áreas de Conservação of the Ministério do Turismo, Mozambique. The management plan for the PNZ was compiled by ecologists Dr D. Grossman and Ms P. Holden. Assistant Park Warden Snr. Sensao and his staff provided logistical support and accompanied the survey team in the field. J. Burrows, E. Schmidt and M. Lötter of the Plant Specialist Group assisted with species identification. The aerial control points were assessed during the aerial wildlife count that was funded by the Projecto Áreas de Conservação Transfronteira e Desenvolvimento do Turismo (ACTFDT) of the Ministério do Turismo. Logistical support was provided during 2007 for the aerial survey by Park Warden Snr A. Abacar, pilot M. Pingo, as well as J. Peel, A. Jacobs, B. Cuthill, B. Olbricht and O. Büchner.

\section{REFERENCES}

Bandeira, S.O., Hatton, J.C., Munisse, P. \& Izidine, S., 1994, 'The ecology and conservation status of plant resources in Mocambique', Strelitzia 1, 105-115.

Coates Palgrave, K., Coates Palgrave, M., Drummond, R.B. \& Moll E.J. (eds.), 2002, Trees of southern Africa, 3rd edn., Struik Publishers, Johannesburg.

Departemento Terra e Agua, 1995, 'Legenda da carta nacional de solos (Escala 1:1000000)', compilada pelo Departemento Terra e Agua, Maputo, Moçambique.

Desanker, P.V., Frost, P.G.H, Frost, C.O., Justice, C.O \& Scholes, R.J. (eds.), 1997, 'The Miombo Network: Framework for a terrestrial transect study of land-use and land-cover change in the miombo ecosystems of Central Africa', IGBP Report
41, The International Geosphere-Biosphere Programme (IGBP), Stockholm, Sweden.

DINAGECA, 1999, 'Carta de Uso e Cobertura da Terra', joint venture IGNFI - CENACARTA - DINAGECA, Moçambique.

DNAC, 2002, 'Zinave National Park, management and development plan', unpublished report to the National Directorate for Conservation Areas, Ministry of Tourism, Republic of Moçambique.

Duarte, P.D. \& Oreste, M.N., 1999, 'Country brief on non-wood forest products: EC-FAO Partnership Programme (19982000)', Project GCP/INT/679/EC data collection and analysis for sustainable forest management in ACP countries.

Edwards, D., 1983, 'A broad-scale structural classification of vegetation for practical purposes', Bothalia 14(3\&4), 705-712.

Gabriel, H.W. \& Talbot, S.S., 1984, 'Glossary of landscape and vegetation ecology for Alaska', BLM-Alaska Technical Report 10, U.S. Department of the Interior.

Gauch, H.G., 1982, Multivariate analysis in community ecology, Cambridge University Press, Cambridge.

Gertenbach, W.P.D., 1983, 'Landscapes of the Kruger National Park', Koedoe 26, 9-121.

Hill, M.O., 1979, TWINSPAN - a FORTRAN program for arranging multivariate data in an ordered two-way table by classification of the individuals and attributes, Cornell University, Ithaca, New York.

Jongman, R.H.G., Ter Braak, C.F.J. \& Van Tongeren, O.F.R., 1987, Data analysis in community and landscape ecology, Wageningen, Pudoc.

Kelly, R.D. \& Walker, B.H., 1976, 'The effect of different forms of land use on the ecology of a semi-arid region in Southeastern Rhodesia', Journal of Ecology 64, 553-576.

Land Type Survey Staff, 1989, 'Land types of the map 2530 Barberton', memoirs of the Agricultural Natural Resources of South Africa 13. 
Leemans, R. \& Cramer, W., 1991, 'The IIASA database for mean monthly values of temperature, precipitation and cloudiness of a global terrestrial grid', International Institute for Applied Systems Analysis (IIASA), RR-91-18.

MICOA, 1997, 'First national report on the conservation of biological diversity in Moçambique', Ministry for the Coordination of Environmental Affairs, Maputo.

Mueller-Dombois, D. \& Ellenberg, H., 1974, Aims and methods of vegetation ecology, John Wiley \& Sons, New York.

National Working Group for Vegetation Ecology, 1986, 'Soil classification according to the binomial classification system', Technical Communication 3.

Peel, M.J.S., Kruger, J.M. \& MacFadyen, S., 2007, ‘Woody vegetation of a mosaic of protected areas adjacent to the Kruger National Park, South Africa', Journal of Vegetation Science 18(6), 807-814.

Scholes, R.J. \& Walker, B.H., 1993, An African savanna, Cambridge University Press, Cambridge.

Siebert, F., Bredenkamp, G.J. \& Siebert, S.J., 2003, 'A comparison of mopaneveld vegetation in South Africa, Namibia and Zimbabwe', Bothalia 33(1), 121-134.

Smithers, R.H.N. \&. Lobão Tello, J.L.P., 1976, 'Check list and atlas of the mammals of Mocambique', Museum Memoir No. 8, Trustees of the National Museums and Monuments of Rhodesia, Bulawayo, Zimbabwe.

Stalmans, M., 1994, 'Vegetation survey of Malilangwe', unpublished report to the Malilangwe Conservation Trust.

Stalmans, M., Gertenbach, W.P.D \& Carvalho-Serfontein, F., 2004, 'Plant communities and landscapes of the Parque Nacional do Limpopo, Moçambique', Koedoe 47(2), 61-81.
Stalmans, M. \& Peel, M., 2007, 'Wildlife survey - Parque Nacional de Zinave, Moçambique', unpublished report by International Conservation Services and Agricultural Research Council for Áreas de Conservação Transfronteira e Desenvolvimento do Turismo - Ministério do Turismo, República de Moçambique.

Stalmans, M. \& Wishart, M., 2005, 'Plant communities, wetlands and landscapes of the Parque Nacional de Banhine, Moçambique', Koedoe 48(2), 43-58.

Storer, R.W. \& Dalquest, W.W., 1967, 'Birds from the Save River of Mozambique', occasional papers of the Museum of Zoology, University of Michigan 62, 1-14.

Ter Braak, C.J.F., 1986, 'Canonical correspondence analysis: A new eigenvector technique for multivariate direct gradient analysis', Ecology 67(5), 1167-1179.

Ter Braak, C.J.F., 1992, CANOCO - a FORTRAN program for canonical community ordination, Microcomputer Power, Ithaca, New York.

Timberlake, J.R., Nobanda, N. \& Mapaure, I., 1993, 'Vegetation survey of the communal lands - north and west Zimbabwe', Kirkia 14(2), 171-270.

Van Rooyen, N., Theron G.K. \& Grobbelaar, N., 1981, 'A floristic description and structural analysis of the plant communities of the Punda Milia-Pafuri-Wambiya area in the Kruger National Park, Republic of South Africa: 2. The sandveld communities', Journal of South African Botany 47(3), 405-449.

Werger, M.J.A. \& Coetzee, B.J., 1978, 'The Sudano-Zambezian region', in M.J.A. Werger (ed.), Biogeography and ecology of southern Africa, pp. 301-454, Dr W. Junk, The Hague. 